\title{
Remediating the irremediable: the Munich air crash and its different narrations
}

\author{
Enrico Martines
}

On 6th February 1958, an air crash at the Munich airport claimed the lives of eight Manchester United footballers, putting the overwhelming rise of the team led by Scottish manager Matt Busby to a tragic end. The "Busby Babes", as they were popularly known, were returning from a victorious European Cup tie against Red Star Belgrade, when their airplane crashed in atrocious weather whilst attempting to take off for the third time from Munich-Riem Airport ${ }^{1}$. The tragedy not only struck English football, as it also affected ordinary people, such was the popularity of this group of young boys, "who were almost the personal friends of millions". This sporting and human tragedy was keenly felt all over Britain; it was an event etched in the memory of a generation. One can say it was the Diana of its day, in an era not given over to false sentiment or emotion.

Such a dramatic circumstance obviously earned itself a particular place in British popular culture. As Danish critic Søren Frank wrote in his cultural analysis of Manchester United, "Today the Munich disaster is a centrepiece of a steadily increasing memory industry, both in and outside the club, which helps to reinforce the mythology and mystery around the Busby Babes" (Frank 2013, 195). It has therefore been the subject of many narrations, and different media have been used to tell it: books have been written, documentaries and movies have been realised, even songs have been composed on this matter, as we can see from the list of references. Each media exploited

\footnotetext{
${ }^{1}$ The accident caused a total of 23 fatalities. They were: Captain Kenneth "Ken" Rayment, Tom Cable (crew members); passengers Geoff Bent, Roger Byrne, Eddie Colman, Duncan Edwards, Mark Jones, David Pegg, Tommy Taylor, Liam "Billy" Whelan (players); Walter Crickmer (club secretary), Tom Curry (trainer), Bert Whalley (chief coach); Alf Clarke, Donny Davies, George Follows, Tom Jackson, Archie Ledbrooke, Henry Rose, Frank Swift, Eric Thompson (journalists); Bela Miklos (travel agent), Willie Satinoff (supporter, racecourse owner and close friend of Matt Busby).
} 
its own peculiarities to stress different aspects of this modern-day myth. The aim of this paper is to analyse how the different remediations of this irremediable incident emphasise different aspects linked to it. I will especially focus my brief analysis on the filmic productions of different kinds - documentaries, docu-dramas, and TV movies - genres which are particularly prone to insert in their productions contents created for other medias, sometimes combining codes and conventions.

The main reason for the great admiration and affection engendered by the Babes was the fact that it was a team built by young, talented and motivated players, mainly coming from the North of England, or scouted elsewhere, and raised through the youth ranks of the club. They had been put together by Matt Busby in a familiar (yet competitive) structure and rapidly projected to the first team: Busby's policy was revolutionary in a football world that was thought to be made only for strong and mature men; nevertheless, his choice paid immediate dividends. This aspect is acutely highlighted in the documentary The Busby Babes: End of a Dream, produced by ITV network in 1998. Their style of play - all flair and attacking football not only had great success in terms of results, as it caught people's imagination and earned the team an almost univocal consensus all over Britain. This particular message is transmitted in the documentary by integrating the cheerful song Manchester United Calypso $^{2}$ as the audio background to the images of footballing skills and people's happiness (05'09'-05'53").

The Babes are portrayed as being at the same time idolised and considered like next-door friends: they were very famous but definitely not rich. The younger and not married players lived together in shared houses, with a landlady. They normally walked the streets of Manchester, went to cinemas and bars like any other Mancunian boy; they were not a world apart from the city's people, as does happen nowadays, they even walked to the football ground amid the fans, or they simply took a bus. Manchester Utd players were a group of young charismatic boys who set the trend and appeared on advertising billboards, but they were loved like family boys. It was like living a dream, both for the players and for the fans.

\footnotetext{
${ }^{2}$ Written by Caribbean singer Edric Connor in 1955, it was the first Manchester United song.
} 
This outstanding football team lifted the spirits of a nation sunk in post-war austerity. The Babes are depicted as a vivid image of Great Britain in the 50's: a nation that was experiencing the peak of postwar consensus, that lived in an optimistic atmosphere (although in a time of grim hardship), that was progressively improving the quality of life, with the end of rationing; there was a young new Queen, a strong sense of decency and solid community ties. Solidarity, respect, and mutual trust, were the crucial values, especially in an industrial, working-class environment such as Manchester. It was a decade of new beginnings: people had a strong desire to be entertained and to identify with something that was positive and successful but, at the same time, very close and familiar, as the Busby Babes were. As David Hall wrote, "In austere, post-war Britain, Busby's Babes represented hope and optimism" (Hall 2008, 288).

The documentary defines the Babes as "gods". In fact, when people first received the news of the crash, they initially assumed it couldn't be that serious, maybe members of the crew could have died, 'not young fit footballers, they wouldn't be dead' (38'50"-39'07'). Clearly, if Manchester United team is represented as an Olympus, one deity is described as being the king of them all, the one that stands above the rest. That was Duncan Edwards, who surrendered to the severe injuries provoked by the crash only after two weeks of desperate struggle. Edward's remembrance is built upon the archetype of the young hero who died too soon. If it is true that the Babes achieved a lot of success at a very young age, they surely didn't have time to fulfil their potential entirely. It is repeated many times that they would have won the European Cup, and would have dominated English and European football for a decade. The "Flowers of Manchester", as they were also called, were picked too soon. Edwards was the complete footballer: contemporaries and teammates, they all agree that he had all the qualities gathered in one player. As artist Harold Riley says (at 49'05"-49'15") "He was the essence, the heart of the whole thing $[\ldots]$ he was in a way symbolic of everything that United stood for": fast, big, strong, brave, gifted, confident, he could break teams individually, win games on his own. Many affirmed that he would have been one of the greatest players of all time, and this can be said because fate made it impossible to prove the contrary. So, the young hero is destined to immortal glory. 
The turning point of this story is Manchester United's search for European success: after their domestic triumph, in 1956 the Babes became the first English team to enter the European Cup, defying English authorities in the process. Matt Busby's European ambitions clashed with the will of the Football League, whose directors were extremely conservative. Secretary Allan Hardaker was known for his xenophobia and insular thinking. Busby thought that Europe was the future, and history would prove him right, so he went to war with the Football League and won: it was the only way to meet and prove their strength with other styles of football. It was another world for players and supporters: they just knew stereotypes about foreign countries, learned from books and movies. Everything was different.

The story of Manchester Utd young heroes battling away in Europe was big news. The papers fuelled the public's imagination. But Europe was not all glamour. Flying was required to get to play abroad, and safety in the air was beyond the player's control. For example, when they had to play in Spain against Athletic Bilbao, they found a very cold climate. It had snowed heavily and the airplane was covered in ice. The pilot wouldn't take-off until the players had swept the wings and the runway. The players were given sweeping brushes; they knew they had to come back in time for the following Saturday's game, otherwise the League would have punished Manchester Utd for not fulfilling the fixtures list. They took that task like a big joke. It was exactly a year before the Munich crash, 6th February 1957, an omen of the disaster to come.

Furthermore, the 50's were the height of the Cold War, a time of fear and suspicion. When Manchester Utd had to fly to Belgrade during their second international campaign, there were reasons for some unrest. Everybody were afraid that they could not find to eat in Eastern Europe, so they packed cans of food in their luggage, only to find out that nourishment in Belgrade was perfectly adequate. The documentary emphasises the fact that the players did not want to fly to Eastern Europe. In fact, what the film omits to say is that the team had already travelled to Prague for the previous round of the European Cup, in December 1957. Czechoslovakia was definitely a communist country, at that time, and Prague was beyond the Iron Curtain just as Belgrade was. Besides, on the way back from Prague, fog over England prevented the team from flying back to Manchester, so they hastily made arrangements to come back by other means, arriving just 
a few hours before their following League fixture. That was the main reason why Busby decided to charter a plane for the next trip to Belgrade. The documentary overlooks the previous travel to Eastern Europe - and the possible feelings generated by it - in order to hint at a possible connection between the perceived danger of going to Yugoslavia and the tragedy that eventually unfolded.

The accident and its tragic consequences caused the emersion of distinctive human values and feelings, among the survivors. Goalkeeper Harry Gregg stood out for his heroic behaviour: out in the snow in the aftermath of the crash, with just a cut on his head, he clambered back into the plane, dragged out two survivors, then, he drew some other passenger yards away from a possible blast of the engines. Two documentaries are dedicated to Harry Gregg's experience: Munich Air Disaster - Harry Gregg's Journey, produced by BBC Northern Ireland in 2008, and Munich Air Disaster: I Was There, filmed for the National Geographic channel, in 2011. In both, Gregg retraces his steps back to Munich, where he poignantly meets a Yugoslav family he saved. Gregg has always diminished the hero tag attached to him, arguing that nobody is a hero and that the contingency of life pushes one to do what comes naturally. His selfimage is that of a player who was the best goalkeeper of the world, for a short time, but also that of a man not different from anybody else, simply a survivor ${ }^{3}$. Harry Gregg is a man from a different age, born before the war, he's a hard man, from the old school, a school that taught duty, discipline and responsibility before self.

Fate made its choices, as it was the case of Geoff Bent who, at the very last minute, joined the squad departing to Belgrade as a cover for the left-back position, due to a minor injury that had put in doubt the presence of captain Roger Byrne. He went instead of young reserve Ronnie Cope. Those who escaped death on that tragic day, experienced the survivor's guilt, asking themselves why they were the lucky ones. Manager Matt Busby was badly injured but he finally recovered. He never forgave himself for taking his boys to Europe. He felt that it was his fault, he blamed himself for not having said anything against the third and fatal attempt to take-off from the slushcovered runway, after the first two had failed for engine problems, under the falling snow. That was the main regret and the main reason

${ }^{3}$ As he affirms in Munich Remembered (15'56"-16'20"). 
for anger for those who were crying their loved ones. As Harry Gregg has declared, if anyone had said "That's crazy, we are not going", the tragedy would have been spared ${ }^{4}$. But human nature makes it difficult to show to anybody fear and weakness. As he said: "All the people were afraid to lose face in front of their friends. It takes a very brave man to be a coward"5.

Documentaries often make use of archive footage to tell their stories. In the case of the BBC series called Nation on film, the attention is on the media as well as on the events narrated. On BBC website, Nation on film is described as a "Documentary series exploring the use of film as an eyewitness to history"6. Two epidodes - Munich Remembered and Sir Bobby Remembers Munich - were dedicated to the Munich air crash and first broadcasted on the evening of 4th February 2008, to mark the 50th anniversary of the tragedy.

Both films repeatedly emphasise the importance of the existence of archive footage as a unique testimony of that great team, who played in an era when there wasn't a great abundance of images. In fact, Munich Remembered presents the only colour footage of the Busby Babes, a film captured on the side-line of the football pitch by an amateur cameraman working for Burnley FC at a match between the two sides, in April 1957. At different points of the documentary, an empty cinema hall is shown while a newsreel is going on the screen, or we can see people, like Sir Bobby Charlton, watching films. This process of mise en abyme, a clear example of hypermediation, whose logic is the imperative that a medium calls attention to itself, naturally makes the consumer sensible to the presence of mediation. It therefore generates a metadiscourse, since the TV documentary remediates a cinema newsreel, which is another kind of documentary produced for another media. The focus is on the film. Cinema was for most people the way through which they learned about the tragedy: so, the attention of the documentary goes to the work of the cameramen of companies like Pathe and Movietone. More than once, the documentary purposely shows the movie headers with the numbers

\footnotetext{
${ }^{4}$ See Munich Air Disaster (Mayday series), 10'43"-11'00".

${ }^{5}$ See The Busby Babes: End of a Dream, 42'42"-43'02".

${ }^{6}$ At the url http://www.bbc.co.uk/programmes/b006xjtm, last accessed January 17, 2014.
} 
countdown, while the noise made by the film roll in the projector is audible, in order to put the emphasis on the archive material.

A fabled story like that of the Busby Babes, so rich in human context and consequence, obviously attracted TV or cinema producers for some sort of adaptation. From the 90's, various projects of film were announced, or gossiped. In the end, the Munich air crash was the subject of various degrees of dramatisation ${ }^{7}$. Two of those could be inscribed in the genre called dramatised documentary, or docu-drama, which is generally a program with a documentary base or core that uses recognisable dramatisation to overcome limitations in the historical record and/or to achieve a more broadly popular and imaginatively powerful effect.

Naturally, the degree to which a particular docu-drama combines the codes and conventions of documentary and drama may vary. The first dramatic portrayal of the disaster was shown on BBC One in 2006: Surviving Disaster - Munich Air Crash, based on eyewitness accounts and interviews with some of the surviving players, tried to reproduce the general atmosphere surrounding the events. A combination of a model and computer-generated imagery was also involved, plus the cockpit of a real plane in a museum.

The main issue with this kind of representation of actual events is their referentiality the tightness of relationship the show claims with real facts. As the producer of the film, Greg Lanning, admitted, "It's clearly a drama, it isn't a documentary", though archive footage, possibly commented by a voice-over, is sometimes used "to remind you that it's actually based on fact", as Lanning added ${ }^{8}$. Most of the program was dramatised, in fact, and the narrator had a total of three short informative interventions. The transition from the re-enactement to the original material is sometimes marked by switching the colour scene to black and white. Surviving Disaster has been criticised for its inaccuracies.

A second docu-drama on this subject was produced in 2011. Munich Air Disaster was part of a Canadian TV documentary series called Mayday (also known in other countries as Air Crash Investigations), dedicated to flight-related disasters and crises with the aim to reveal their causes and consequences. For the purpose, it used

\footnotetext{
${ }^{7}$ See the sections "Docu-dramas" and "Tv Film" in the list of references.

${ }^{8}$ See webpage Munich '58: TV Drama.
} 
re-enactments and computer-generated imagery. Clearly, it exhibits a more factual approach compared with that of the previous production. Actually, the documentary begins with this statement: "This is a true story. It is based on official reports and eyewitness accounts. Certain scenes have been altered for dramatic purposes" (01'15"-01'21"). The alternation between drama and documentary is much quicker than in Surviving Disaster; the actors speak just a few lines, the re-enactments are mostly used to enrich the visual aspect of the program, while the voice-over, the witnesses and the experts tell the story. All along the film, there is a fast transition between the plan of reality - testimonies, pictures, documents - and that of dramatisation. The re-enacted scenes mainly focus on the technical and procedural aspects of the story. Aviation experts are interviewed to give their opinion on the causes of the accident. One of them is Stephen Morrin, author of the book Munich Air Disaster: he is an aviation historian and this program appears to be based on his work. Primary attention is given to the accident, rather than to football or to the social context of Manchester United in the 50's. More than half of the documentary is dedicated to the investigation on the causes of the crash, which is reconstructed in details. The main character is clearly Captain James Thain and his battle against injustice. After the death of his co-pilot, Thain found a finger of blame pointed at him. The official investigation led by the German authorities indicated Thain as the sole responsible for his failure to sweep the wings of ice and he was fired by the BEA. But later official tests revealed the cause had actually been slush on the runway, which slowed the aircraft and made take-off impossible. In 1969, British authorities officially cleared Thain from the responsibility of the disaster. Even so, the BEA did not give him his job back and he never flew again. Thain died young at 54, one can say he was the $24^{\text {th }}$ victim of the tragedy. The film highlights the delicate situation created by the disaster, at a diplomatic level: two pilots who flew for the RAF during the Second World War involved in an accident occurred in Munich, the former heart of the Nazi regime. German authorities did everything to put the blame on the pilot and hide their own responsibilities, while the British government tried in every way to avoid a diplomatic incident. At the end, the program stresses the legacy of Captain Thain's investigation, which led to considerable progress in civil aviation, as far as the problems created by slush on the runway, during take-off, are concerned.. 
In 2011, the BBC produced a TV drama called United. It is a dramatisation that uses the "based on" formula, as indicated in the first frame, which shows the line "The following story is based on real events". The drama primarily focuses on the relationship between assistant manager Jimmy Murphy and the young player Bobby Charlton. Director James Strong declared: "in making a drama rather than a documentary, we had to make editorial choices. We never intended this film to be the definitive story of the Babes and the crash - that would be impossible. For me, drama works best when it focuses on one or two people. So our film is only one story, one aspect" (Strong 2011).

It's interesting how, at the beginning of the story, the film shows what we should call an enacted remediation: we see people at a cinema watching a staged black and white newsreel which deals with the beginning of a new season for Manchester United. In the simulated news movie, actors interpret the players; at the cinema, the same players are watching it, responding to the people's cheers when the voice-over calls their names, thereby setting the historical context of the movie and presenting the role played by each actor.

The dramatisation is quite keen in setting the framework of the story. When Bobby Charlton asks coach Jimmy Murphy when he will be given his chance to play for the first team, Murphy gives him a speech which is essential to explain the social background and consequently the function of this team in England's most important industrial city, how they represent a source of pride of all the workers (06'40"-07'38"). Typical working-class qualities, like hard work and competitiveness, are emphasised as the main ingredients to achieve and maintain success; solidarity from normal people is highlighted after the tragedy.

This film underlines the conflict between Matt Busby and Allan Hardaker as the main factor that led to the tragedy. Sometimes, this interpretation of the facts is stretching the point a bit, for the need of dramatisation.

Inaccuracies have been pointed out, once more, by Munich's survivors and by the relatives of people involved in the accident. Sandy Busby, son of manager Matt, described the production as a "piece of rubbish" which made his father look like a gangster, putting him in a long overcoat and a trilby hat, and never portraying him in a tracksuit, while he was one of the first post-war manager to work on 
the training pitch. Harry Gregg said the film was an "embarrassment" and added he asked for his name to be removed from the credits; he said the film portrayed Manchester United as a pub team, giving a false picture of football at that time: particularly, the scenes where player Mark Jones is shown smoking a pipe in the dressing-room or in the tunnel before a game (18'47"-21'42") were an "affront" to the dead (Graham 2011).

Probably, the most important aspect stressed by this film was the rebirth of the club, after the tragedy had put its continuation in real danger. Although someone in the directing board had pushed for the retirement of the team from competition, coach Jimmy Murphy decided to face the stern task of rebuilding the squad. Despite losing most of their league games, the new team had an incredible run to the FA Cup final, showing their resilience and will to exist. Busby came back for the first time to see the great game. In United, the scene shows him addressing the team and pointing at the new club's badge, sewn on the shirts for the occasion: a phoenix rising from the ashes, he says ( $1 \mathrm{~h} 25^{\prime} 57^{\prime}$ '- $1 \mathrm{~h} 27^{\prime} 00$ "). In reality, the bird on the badge is not a phoenix at all: it is actually an eagle, taken from the 1958 city of Manchester coat of arms. The use of this badge for that particular game had been announced in the Manchester Evening News, which mentioned the resemblance of the bird to a phoenix rising out of the ashes: maybe, that was the source of the rumors about it. The myth was later reprised and made popular by the BBC drama, which emphasised the resurgence of the club and paid a tribute to the role played in it by Murphy, whose character says: "No, it's not about their memory. It's about showing who we are to the world. Showing we'll not be bowed by tragedy. Because how we are in the future will be founded on how we behave today" (1h13'07'-1h13'21').

In fact, as Jim White wrote on The Telegraph, quoting goalkeeper Harry Gregg:

because of what happened in Munich, Manchester United changed from being a football club into an institution. It was the point when United became culturally dominant. The myth of the disaster grew not from the early death of eight young footballers, but from the insistence that the club would not capitulate. [...] What cements loyalty is success in the face of adversity. (White 2013) 
Italian club Torino suffered an even more devastating air trauma a decade before, but they never recovered their previous position of preeminence and are now an average club, whose glory died on the Superga hill. Munich is central to Manchester United history for this reason: the club triumphed over it. And that's why this story keeps on being narrated.

\section{References}

Books:

ConnoR, J., 2006, The Lost Babes: Manchester United and the Forgotten Victims of Munich, Harper Sport, London.

FRANK, S., 2013, Standing on the shoulders of giants: a cultural analysis of Manchester United, Bloomsbury Publishing, London.

HALl, D., 2008, Manchester's Finest: How the Munich Air Disaster Broke the Heart of a Great City, Windsor/Paragon, Bath.

MorRIN, S. R., 2007, The Munich Air Disaster, Gill \& Macmillan, Dublin.

RoBerTs, J., 1998, The Team That Wouldn't Die: The Story of the Busby Babes, Vista, London.

TAYLOR, F., 1998, The Day a Team Died: The Classic Eye-Witness Account of Munich 1958, Souvenir Press, London.

Articles and web pages:

ANON., "Munich '58: TV Drama", BBC Manchester, available at http://www.bbc.co.uk/manchester/content/articles/2005/12/15/161205_m unich_air_crash_feature.shtml, last accessed January 17, 2014.

GRAHAM B., 2011, "BBC's Munich air crash film is 'insulting rubbish': Matt Busby's son says $£ 2 \mathrm{~m}$ football drama portrays his father as a gangster", Daily Mail, April 25, available at http://www.dailymail.co.uk/news/ article-1379752/Busbys-son-disgusted-BBCs-Munich-air-crash-filmsportrayal-father-Matt. html\#ixzz2cgy4vxqY, last accessed January 17, 2014.

STRONG J., 2011, "United: Busby Babes and the Munich air crash”, BBC TV Blog, 24 April, available at http://www.bbc.co.uk/blogs/tv/posts/unitedmunich-james-strong, last accessed January 17, 2014.

WHITE J., 2013, "Jimmy Murphy's central part in the resurrection of Manchester United is the key reason to watch United", The Telegraph, April 22, http://www.telegraph.co.uk/sport/football/teams/manchesterunited/8467086/Jim-White-Jimmy-Murphys-central-part-in-theresurrection-of-Manchester-United-is-the-key-reason-to-watchUnited.html, last accessed January 17, 2014. 
Documentaries:

Munich Air Disaster - Harry Gregg's Journey (One Life series, season 10, episode 1), 2008, BBC Northern Ireland.

Munich Air Disaster: I Was There, 2011, National Geographic.

Munich Remembered (Nation on Film series), 2008, BBC.

Sir Bobby Remembers Munich (Nation on Film series), 2008, BBC.

The Busby Babes: End of a Dream, 1998, directed by Alan Brown, ITV.

Docu-dramas:

Munich Air Disaster (Mayday series, season 11, episode 5), 2011, directed by James Hyslop, produced by Cinefix Productions, Canada.

Surviving Disaster - Munich Air Crash, 2006, directed by Matthew Wortman, BBC.

Tv Film:

United, 2011, directed by James Strong, produced by World Production.

Songs:

Munich Air Disaster, 1958, 2004, composed and performed by Morrissey.

News and Tributes, 2006, composed and performed by The Futureheads.

The Flowers of Manchester, 1958, composed by anonymous, performed by The Spinners. 